\title{
Correction to: Pharmacologic Treatment of Pediatric Hypertension
}

Michael A. Ferguson

\section{Correction to:}

\section{Chapter 44 in: J.T. Flynn et al. (eds.), Pediatric Hypertension, https://doi.org/10.1007/978-3-319-31107-4_36}

The book was inadvertently published with incorrect text in Table 3. The text has been corrected in the table to read as follows:

The maximum dose for Captopril is $6 \mathrm{mg} / \mathrm{kg} / \mathrm{day}$. 